\title{
RISK FACTORS OF INFERTILITY CASES AMONG SHALLOT FARMERS
}

\author{
Sri Winarni ${ }^{1}$, Hanifa M. Denny ${ }^{2}$, Dharminto ${ }^{1}$, Fahmi Arifan ${ }^{3}$, Ari Suwondo ${ }^{2}$, Apoina Kartini ${ }^{4}$ and \\ Hardhono Susanto ${ }^{5}$
}

${ }^{1}$ Department of Biostatistics and Population, Faculty of Public Health, Diponegoro University, Semarang, 50275, Indonesia, +628122893069, winarniwiwin1975@gmail.com

2Department of Occupational Safety and Health, Faculty of Public Health, Diponegoro University, Semarang, 50275, Indonesia, +62811296228, hanifadenny@live.undip.ac.id

${ }^{3}$ Programme Diploma of Chemical Engineering, Faculty of Engineering, Diponegoro University, Semarang, 50275, Indonesia, +6281328308984, fahmiarifan80@gmail.com

${ }^{4}$ Department of Public Health Nutrition, Faculty of Medicine, Diponegoro University, Semarang, 50275, Indonesia, +628122939166, apoinakartini@yahoo.com

${ }^{5}$ Faculty of Medicine, Diponegoro University, Semarang, 50275, Indonesia, +62811272242,

Corresponding author: Sri Winarni

Email: winarniwiwin1975@gmail.com

\begin{abstract}
The result from preliminary survey showed that the prevalence of couples in childbearing age who used pesticide excessive in the shallot farming and did not have offspring for $>1$ year in Pamulihan Village, Larangan Subdistrict, Brebes was 33\%. This study aimed to analyze occurrence of male infertility according to their practices on pesticide use and zinc-containing diets. The design study was case-control and data was collected by using the standardized questionnaires. From total of 81 cases and 581 control males, respondents of 51 cases and 51 controls were selected with random sampling method. The investigators measured the use of pesticides, personal protective equipment, practices on the daily use of clothing, handwashing after spraying, and zinc intake. The multivariate analysis result indicated that the variables that exhibited a significant effect were the frequency of pesticide spraying in a week (OR: 2. $663(\mathrm{Cl}=1.138-6.233))$, spraying against the wind direction $(0 R: 0.180(\mathrm{Cl}=0.033-0.971))$, and repeated spraying (OR: $0.346(\mathrm{Cl}=0.146-0.819))$. Although factor farmers worked more than six hours per day, practiced respraying, consumed fertility-enhancing foods and used the PPE were identified as a significant risk factor of infertility in univariate analysis, the association becomes disappeared in multivariate analysis. It might be due to multiple combination effect between variables. Frequency of pesticide spraying in a week was the variable with the highest effect, which is farmers who sprayed the pesticide on the red shallot $>3$ times per week were inclined in infertile three times higher.
\end{abstract}

Keywords: pesticides; shallot farmer; infertility; reproductive health.

\section{INTRODUCTION}

Infertility is one of the public health problems worldwide. Infertility is a reproductive disorder that affects couples who are actively engaged in sexual intercourse for one year without any contraception but do not have children or the inability to get pregnant for a woman who is engaged in sexual intercourse with a $\operatorname{man}^{1,2}$. Infertility is a disease of the reproductive system defined by the failure to achieve a clinical pregnancy after 12 months or more of regular unprotected sexual intercourse. ${ }^{1}$ Infertility treatment for men and women becomes challenging and competitive in its clinical technology and business ${ }^{2,3}$.

The estimated prevalence of infertility ranged from $3.5 \%$ to $16.7 \%$ in developed countries, while in developing countries, it is slightly different, from $6.9 \%$ to $9.3 \%$. The proportion of couples seeking medical treatment due to infertility is higher in developed countries, $56.1 \%(42-76.3 \%)$, compared to developing countries, $51.2 \%$ (27$74.1 \%)^{4}$. The Indonesian health services and demographic health survey estimated that infertility cases in Indonesia ranged from $10 \%$ to $22 \%{ }^{5}$. An estimated $10 \%$ of couples out of 39.8 million childbearing age couples need infertility treatment to have offspring ${ }^{6}$. The researcher conducted a preliminary survey and found out that the prevalence of couples of childbearing age who did not have offspring for $>1$ year in Pamulihan Village, Larangan Subdistrict, Brebes was $33 \%$.

Infertility is a threat to a woman's social welfare and security. Cultural or socio-cultural influence in various tribes in Indonesia could affect the stress experienced by infertile couples, especially among women or wives. A suspected connection also exists between male fertility and sexual dysfunction. Infertile men often believe that their identity and masculinity are not perfect ${ }^{7}$.

Forty percent of infertility cases generally suffer males, $40 \%$ females, and the rest was the disorder of both males and females ${ }^{8}$. Infertility is associated with the endocrine system. Daily Zinc intake from food in some countries ranges from 4.7-18.6 mg / day9. Household food consumption 
shows that Zinc intake in Southeast Asian countries is quite low at nine $\pm 0.9 \mathrm{mg} / \mathrm{day}$. Adequacy of Zinc in adulthood is $13 \mathrm{mg} /$ day $^{10}$. Studies of the effects of zinc supplementation on FSH show that zinc can increase the amount of $\mathrm{FSH}^{11}$. Sufficient zinc can synthesize testosterone, improve spermatogenesis, and increase fertility ${ }^{12}$. A local agricultural officer informed that farmers in Brebes are accustomed to using a mixture of pesticides of more than five types. During the shallot season, they spray the shallots with pesticides every two days. However, not many studies looked at the relationship of risk factors for pesticide exposure and zinc-containing diets to farmers exposed to pesticides. Therefore, this study aimed to analyze the effect of exposure to pesticides and zinc-containing diets on farmer infertility.

\section{METHODS}

This case-control design study applied an indepth interview using standardized questionnaires. The inclusion of the cases group was shallot farmer, male, pesticides sprayer more than a year, age between 20 to 40 years old, married more than a year but still no kid, exhibit a healthy sexual activity ( 2 to 3 times a week), and the non-contraceptive user. Conversely, the inclusion criteria for the control group were shallot farmer, male, pesticide sprayer more than a year, age between 20 to 40 years old, and have at least one child or a kid with the length of being married more than one year. Between cases and controls, most respondents were in the normal Body Mass Index group, age $\leq 40$ years ago, and active smokers > 10 cigarettes/day.

This study utilized a random sampling method following the Lemeshow formula. From total population at 81 cases, researchers obtained samples of 51 subjects for case, and from total population at 581 controls, researchers obtained samples of 51 control subjects. The investigators collected data using the structured questionnaire interview on the use of pesticides, including the following:

1. The number of pesticide compounds is the number of pesticides used as a spraying mixture on the shallot field, i.e., organophosphates, pyrethroids, dithiocarbamates, and carbamates: (1) $>2$ types of pesticides; $(0)<=2$ types of pesticides.

2. Type of pesticide compound is the type of pesticide used: (1) nonorganophosphate (pyrethroid and dithiocarbamate); (0) Organophosphates (organophosphates and carbamates);

3. The number of pesticide brand is the number of the trademark of pesticides used for spraying: (1) >5 pesticide brands; $(0)<=5$ brands of pesticides.
4. The frequency of pesticide spraying in a week is the number of spraying pesticides in one week: (1) >3 times/week; $(0)<=3$ times/week.

5. The duration of work daily is the duration of the farmer's work every day: (1) $>6$ hours/day; (0) <= 6 hours/day.

6. The length of being a farmer is the length of time the respondent works as a farmer (in years: (1) Old ( >10 years); (0) New (<= 10 years).

7. Job tasks are the actual tasks in the shallot farming works: (1) All tasks (from land preparation to harvesting); (0) spraying pesticides task only.

8. PPE (Personal Protective Equipment) use is the use of complete Personal Protective Equipment (PPE) when spraying pesticides including the use of masks, face and body protection, gloves, and boots: (1) no mask; (0) wear mask

9. The location of shallot storage is the distance between the storage of crops and the family room (where the family does many activities): (1) < 5 meters from the family room; $(0)>=5$ meters from the family room.

10. Spraying against the wind direction is the face position during pesticide spraying according to wind direction:(1) Yes, opposite; (0) No.

11. Repeated spraying is the re-spraying activity carried out after the harvest process: (1) Yes, there was re-spraying; (0) No.

12. Clothing hygiene is the habit of changing clothes at home after working on spraying pesticides: (1) Same clothing after work; (0) Yes, change clothes.

13. Hand hygiene is the practice of washing hands with soap and running water after spraying pesticides: (1) No handwashing practice; (0) Washing hands.

14. Foods fertility functional is the intake of foods that are good for fertility, for example: salmon, squid, chocolate, duck meat, chicken meat, and fish (1) No (Less); (0) Yes (Adequate).

15. Food fertility inhibitor is the intake of foods that are inhibitor for fertility, for example: high-fiber vegetables, meat, cheese, ice cream, and butter (1) Yes (Adequate); (0) No (Less).

16. Zinc intake, the intake of zinc contains in foods: (1) Less; (0) Adequate.

The diet of pesticide spraying farmers containing zinc was taken using semi FFQ (Food Frequency Questionnaire) and recall food two days, regular days (Monday to Friday) and weekends, which are open-ended questionnaire type.

The study utilized SPSS $₫$ for Windows $₫$ ver 20 software and employed Chi-square tests to analyze the data. Furthermore, to analyze 
occurrence of male infertility incidence according to their practices on pesticide use and zinc-containing diets on farmer infertility, this study applied logistic regression, adjusted for confounders from the Body Mass Index, age, and active smoker variables, with $p$-value $<0.05$ as the cut point of statistical significance.

\section{RESULTS}

This study found that only six variables were related to infertility cases. The first variable was the frequency of spraying every week, with a pvalue $0.029(<0.05)$ and with $O R=2.4(1.1-5.4)$. The second variable is the daily duration of work, with a p-value $0.044(<0.05)$ and with $\mathrm{OR}=$ $2.3(1.0-5.1)$. The third variable is the job task, with a $p$-value $0.046(<0.05)$ and with $O R=0.2$
(0.04-1.1). The fourth variable is the PPE use, with a p-value $0.046(<0.05)$ and with $\mathrm{OR}=4.6$ $(0.9-22.6)$. The fifth variable is the repeated spraying, with a p-value $0.016(<0.05)$ and with $\mathrm{OR}=0.4(0.2-0.8)$. The sixth variable is the foods fertility functional, with a p-value $0.029 \quad(<0.05)$ and with $\mathrm{OR}=0.4(0.2-0.9)$. The six related variables were tested by multiple logistic regression with the enter method.

Most respondents present with a normal BMI, with an average of length of married 5-15 years, age 33-40 years, and are heavy smokers $(>11$ cigarettes smoked per day), both case and control respondents.

Table 1. Respondent Characteristics

\begin{tabular}{|c|c|c|c|c|}
\hline \multirow[t]{2}{*}{ Categories } & \multicolumn{4}{|c|}{ Respondent } \\
\hline & Case & $\%$ & Control & \\
\hline \multicolumn{5}{|l|}{ Body Mass Indeks } \\
\hline Very thin & 0 & 0.0 & 1 & 2.0 \\
\hline Thin & 4 & 7.8 & 6 & 11.8 \\
\hline Normal & 41 & 80.4 & 36 & 70.6 \\
\hline Fat & 4 & 7.8 & 5 & 9.8 \\
\hline Obese & 2 & 3.9 & 3 & 5.9 \\
\hline Total & 51 & 100.0 & 51 & 100.0 \\
\hline \multicolumn{5}{|l|}{ Length of Married } \\
\hline$<5$ years & 13 & 25.5 & 4 & 7.8 \\
\hline $5-15$ years & 27 & 52.9 & 25 & 49.0 \\
\hline$>15$ years & 11 & 21.6 & 22 & 43.2 \\
\hline Total & 51 & 100.0 & 51 & 100.0 \\
\hline \multicolumn{5}{|l|}{ Age } \\
\hline$<30$ & 13 & 25.5 & 12 & 23.5 \\
\hline $30-40$ & 25 & 49.0 & 25 & 49.0 \\
\hline$>40$ & 13 & 25.5 & 14 & 27.5 \\
\hline Total & 51 & 100.0 & 51 & 100.0 \\
\hline \multicolumn{5}{|l|}{ Status of Smoker } \\
\hline Light smokers & 16 & 31.4 & 14 & 27.5 \\
\hline Heavy smokers & 25 & 49.0 & 22 & 43.1 \\
\hline Non smokers & 10 & 19.6 & 15 & 29.4 \\
\hline Total & 51 & 100.0 & 51 & 100.0 \\
\hline
\end{tabular}


Table 2. Pesticide factors and eating patterns

\begin{tabular}{|c|c|c|c|c|c|c|}
\hline \multirow[t]{3}{*}{ Categories } & \multicolumn{4}{|c|}{ Respondent } & \multirow[t]{3}{*}{ p-value } & \multirow[t]{3}{*}{ OR } \\
\hline & \multicolumn{2}{|c|}{ Case } & \multicolumn{2}{|c|}{ Control } & & \\
\hline & $f$ & $\%$ & f & $\%$ & & \\
\hline Number of pesticide compound & & & & & 0.490 & $0.7(0.3-1.8)$ \\
\hline 1). $>2$ types & 11 & 21.6 & 14 & 27.5 & & \\
\hline 0$). \leq 2$ types & 40 & 78.4 & 37 & 72.5 & & \\
\hline Total & 51 & 100 & 51 & 100 & & \\
\hline Type of pesticide compound & & & & & 0.204 & $1.9(0.7-5.4)$ \\
\hline $\begin{array}{l}\text { 1). Non-Organophosphate } \\
\text { (dithiocarbamate, pyrethroid) }\end{array}$ & 12 & 23.5 & 7 & 13.7 & & \\
\hline 0). Organophosphate dan carbamate & 39 & 76.5 & 44 & 86.3 & & \\
\hline Total & 51 & 100 & 51 & 100 & & \\
\hline Number of pesticide brand & & & & & 0.282 & $1.6(0.7-3.7)$ \\
\hline 1). $>5$ & 13 & 25.5 & 18 & 35.3 & & \\
\hline 0$). \leq 5$ & 38 & 74.5 & 33 & 64.7 & & \\
\hline Total & 51 & 100 & 51 & 100 & & \\
\hline Frequency of pesticide spraying in a week & & & & & 0.029 & $2.4(1.1-5.4)$ \\
\hline 1). $>3$ & 33 & 64.7 & 22 & 43.1 & & \\
\hline 0$). \leq 3$ & 18 & 35.3 & 29 & 56.9 & & \\
\hline Total & 51 & 100 & 51 & 100 & & \\
\hline The daily duration of work. & & & & & 0.044 & $2.3(1.0-5.1)$ \\
\hline 1). $>6$ hours & 25 & 49.0 & 35 & 68.6 & & \\
\hline 0$).<=6$ hours & 26 & 51.0 & 16 & 31.4 & & \\
\hline Total & 51 & 100 & 51 & 100 & & \\
\hline The length of being a farmer & & & & & 0.124 & $0.5(0.2-1.2)$ \\
\hline 1). $>10$ years & 33 & 64.7 & 40 & 78.4 & & \\
\hline 0$). \leq 10$ years & 18 & 35.3 & 11 & 21.6 & & \\
\hline Total & 51 & 100 & 51 & 100 & & \\
\hline Job task & & & & & 0.046 & $0.2(0.04-1.1)$ \\
\hline 1). All tasks & 43 & 84.3 & 49 & 96.1 & & \\
\hline 0). Spraying only & 8 & 15.7 & 2 & 3.9 & & \\
\hline Total & 51 & 100 & 51 & 100 & & \\
\hline PPE use & & & & & 0.046 & $4.6(0.9-22.6)$ \\
\hline 1). No & 8 & 15.7 & 2 & 3.9 & & \\
\hline 0$)$. Yes & 43 & 84.3 & 49 & 96.1 & & \\
\hline Total & 51 & 100 & 51 & 100 & & \\
\hline The location of shallot storage & & & & & 0.073 & $0.5(0.1-1.1)$ \\
\hline 1). $<5$ meters from living room & 18 & 35.3 & 27 & 52.9 & & \\
\hline 0$)$. $\geq 5$ meters & 33 & 64.7 & 24 & 47.1 & & \\
\hline Total & 51 & 100 & 51 & 100 & & \\
\hline Spraying against the wind direction & & & & & 0.291 & $0.5(0.1-1.9)$ \\
\hline 1). Yes & 9 & 50.0 & 14 & 66.7 & & \\
\hline 0$)$. No & 9 & 50.0 & 7 & 33.3 & & \\
\hline Total & 18 & 100 & 21 & 100 & & \\
\hline Repeated spraying & & & & & 0.016 & $0.4(0.2-0.8)$ \\
\hline 1). Yes & 15 & 29.4 & 27 & 52.9 & & \\
\hline 0). No & 36 & 70.6 & 24 & 30.0 & & \\
\hline Total & 51 & 100 & 51 & 100 & & \\
\hline Clothing hygiene & & & & & 0.461 & $0.6(0.1-2.5)$ \\
\hline 1). No (same clothes from work) & 3 & 5.9 & 5 & 9.8 & & \\
\hline 0$)$. Yes & 48 & 94.1 & 46 & 90.2 & & \\
\hline Total & 51 & 100 & 51 & 100 & & \\
\hline Hand hygiene & & & & & 0.367 & $0.6(0.2-1.9)$ \\
\hline 1). No & 39 & 88.6 & 41 & 82.0 & & \\
\hline 0$)$. Yes & 5 & 11.4 & 9 & 18.0 & & \\
\hline Total & 44 & 100 & 50 & 115 & & \\
\hline Foods fertility functional & & & & & & \\
\hline 1). Less & 20 & 39.2 & 31 & 60.8 & 0.029 & $0.4(0.2-0.9)$ \\
\hline 0$)$. Adequate & 31 & 60.8 & 20 & 39.2 & & \\
\hline Total & 51 & 100 & 51 & 100 & & \\
\hline Food fertility inhibitor & & & & & & \\
\hline 1). Adequate & 22 & 43.1 & 28 & 54.9 & 0.235 & $0.6(0.3-1.4)$ \\
\hline 0$)$. Less & 29 & 56.9 & 23 & 45.1 & & \\
\hline Total & 51 & 100 & 51 & 100 & & \\
\hline Zinc intake & & & & & & \\
\hline 1). Less & 26 & 51.0 & 31 & 60.8 & 0.319 & $0.7(0.3-1.5)$ \\
\hline 0). Adequate & 25 & 49.0 & 20 & 39.2 & & \\
\hline Total & 51 & 100 & 51 & 100 & & \\
\hline
\end{tabular}


After analyzing the relationship of the independent variables, researchers then carried out the analysis of the influence in common between independent and dependent variables. In this study, the logistic regression was carried out on the 16 independent variables, which is category of number of pesticide compound, type of pesticide compound, number of pesticide brand, frequency of pesticide spraying in a week, the daily duration of work, the length of being a farmer, job task, PPE use, the location of shallot storage, spraying against the wind direction, repeated spraying, clothing hygiene, hand hygiene, foods fertility functional, food fertility inhibitor, and zinc intake, by using simple logistic regression and multiple logistic regression.

Before analyzing the influence in common between independent and dependent variables, a bivariate logistic analysis was performed using the enter method. If the result of bivariate test exhibits a $p$-value $<0.25$, the variable can be entered into the multivariate model. This following table shows the results of the bivariate logistic regression test:

Table 3. The results of the bivariate test used logistic regression

\begin{tabular}{|c|c|c|}
\hline No & Variable & $p$-value \\
\hline 1 & Number of pesticide compound & 0.491 \\
\hline 2 & Type of pesticide compound & 0.208 \\
\hline 3 & Number of pesticide brand & 0.283 \\
\hline 4 & Frequency of pesticide spraying in a week & 0.030 \\
\hline 5 & The daily duration of work & 0.046 \\
\hline 6 & The length of being a farmer & 0.127 \\
\hline 7 & Job task & 0.064 \\
\hline 8 & PPE use & 0.064 \\
\hline 9 & The location of shallot storage & 0.074 \\
\hline 10 & Spraying against the wind direction & 0.239 \\
\hline 11 & Repeated spraying & 0.017 \\
\hline 12 & Clothing hygiene & 0.466 \\
\hline 13 & Hand hygiene & 0.256 \\
\hline 14 & Foods fertility functional & 0.031 \\
\hline 15 & Food fertility inhibitor & 0.236 \\
\hline 16 & Zinc intake & 0.320 \\
\hline
\end{tabular}

This showed that 16 variables were included in the multiple logistic regression test. In the multiple regression test, the analysis of the joint effects of the 16 independent variables was carried out using the forward method. This following table shows the results of multiple logistic regression analysis using the forward method:

Table 4. The results of the logistic regression test.

\begin{tabular}{llcccc}
\hline $\begin{array}{c}\text { Logistic } \\
\text { Regression Test }\end{array}$ & Independent Variable & B & Sig. & OR & Cl(95\%) \\
\hline Model 3 & $\begin{array}{l}\text { Frequency of pesticide } \\
\text { spraying in a week }\end{array}$ & 0.980 & 0,024 & 2.663 & $1.138-6.233$ \\
& $\begin{array}{l}\text { Spraying against the } \\
\text { wind direction }\end{array}$ & -1.715 & 0,046 & 0.180 & $0.033-0.971$ \\
& Repeated spraying & -1.063 & 0,016 & 0.346 & $0.146-0.819$ \\
& Constant & 1.469 & 0.091 & 4.343 & \\
\hline
\end{tabular}

Hosmer and Lemeshow ( $p$-value 0,975); r-square 0,189 
Based on the table above, it can be seen that the results of homes and lemeshows show a $p$-value = $0.975>0.05$, so that the data are fit with the model of logistic regression, and researchers obtained a $r$-square $=0.189$, which means the variable frequency of spraying in a week, spray against the wind, and re-spraying of crop yields contributed to infertility cases in onion farmers $(18.9 \%)$, whereas $(81.1 \%)$ came from other factors outside the model that contributed to infertile cases in onion farmers.

In addition, the table above shows that in the third model, which is the final result of the multivariate analysis using the forward method, an influence of the independent variable frequency regarding spray per week, work division, and re-spraying of crops is present.

Based on the analysis of multiple logistic regression tests, the frequency of spraying often exhibits an effect in the amount of 2.663 times greater in the case of infertility happening in onion farmer, while the work and re-spraying sections act as protective factors, with an OR less than 1.

The joint probability between the frequency of spraying per week, spray against the wind, and re-spraying of the yield affects the infertility cases in onion farmers: 0.418. Based on the logistical equation, the result is 0.418 , which demonstrates that the frequency of spray per week, spray against the wind, and re-spraying of crops together exhibits a probability of infertile cases in onion farmers of $41.8 \%$.

The variables that exhibited a significant effect were the frequency of pesticide spraying in a week (OR: 2. $663(\mathrm{Cl}=1.138-6.233))$, spraying against the wind direction $(\mathrm{OR}: 0.180(\mathrm{Cl}=0.033-$ $0.971)$ ), and repeated spraying (OR: $0.346(\mathrm{Cl}$ $=0.146-0.819))$. The variable with the highest effect was frequency of pesticide spraying in a week. Farmers with the frequency of pesticide spraying the red shallot $>3$ in a week exhibited an infertile tendency 3 times higher than farmers who did spray pesticide $\leq 3$ in a week.

\section{DISCUSSION}

This study showed that number of pesticide compound and the number of pesticide brand were not risk factors for infertility. Data collecting related to pesticide use did not ask for the amount (cc) used. Previous studies found that exposure to chronic or low-level pesticides was not traceable in the reproductive tract. Previous studies revealed that exposure to organophosphate (OP) in the same concentration significantly impacted fetuses and infants' growth and development compared to adults ${ }^{13}$. The operational definition of the grouping of low-level exposure to OP in those studies was not standardized and complicated the determination of OP exposure levels ${ }^{14}$. The nature of the pesticide mixture can low-levels or antagonistic ${ }^{15}$. Pesticides that are estrogen agonists include methoxychlor, endosulfan, toxaphene, kepone, DDT, fenarimol, alpesticidentachrophenol, fenvalerate, and chlordecone. Pesticides that exhibit antiandrogenic activity/botmethoxychloractivity and antiandrogenic vinclozolin include $\mathrm{p}, \mathrm{p}$ dichlorodiphenyldichlorethylene (DDE) and o,p$\mathrm{DDT}^{16}$.

Organophosphate group pesticides are the common pest control in shallot farming. The metabolism of organophosphate (OP) pesticides enters as dialkyl phosphate (DAP). Although widely used, its potential effects on the human reproductive system cannot be fully characterized ${ }^{17}$. Several studies showed associdialkyl phosphates metabolites, DAP, and changes in sperm quality. ${ }^{18}$ Another study found that exposure to OP pesticides combined with other non-persistent pesticides (pyrethroids) showed a negative correlation with sperm concentration ${ }^{18}$.

Frequency of pesticide spraying in a week, the daily duration of work, job task, PPE use, repeated spraying, and foods fertility functional were significantly associated with infertility.

The duration of being a farmer, the location of shallot storage, and spraying against the wind direction were not significantly associated with infertility. Farmers work in open places, the shallot fields, which were very much affected by wind direction. The use of personal protective equipment was associated with the incidence of health complaints, such as dizziness and nausea. PPE that can protect farmers from excuse to pesticides are head protection, hands scoon, and rubber gloves or boots. The use of head protection exhibits a strong enough relationship with the respondent's health complaints $(r=$ 0.318)..$^{19,20}$

The lack of awareness and improper use of personal protective equipment made the exposure worse, e.g., farmers covered their noses with only $\mathrm{t}$-shirts and handkerchiefs. Thes farmers did not use gloves when thinning and pouring pesticides into the spray tank. The increase in hazard awareness from the pesticides among 26 Mexican-American migrant farmworkers in Baytown at Texas was in line with the increased use of personal protective equipment, such as gloves and shoes ${ }^{21}$. The unsafe use of pesticides can be considered a threat to human health and the environment. The use of maximum personal protective equipment can reduce the risk of infertility ${ }^{22}$. Farmers who present with experienced health problems due to the use of pesticides tend to use alternative pesticides that are environmentally friendly to reduce the arising risk of pesticides ${ }^{23}$. 
Some farmers could recognize the effects of pesticides, and they decided to stay away from consuming alcohol, cigarette smoking, and eating fertility-enhancing foods such as salmon, squid, chocolate, duck meat, chicken, fish. ${ }^{24}$ In this research, only $43.1 \%$ farmers usually consume one cup of alcohol daily; however, $74.6 \%$ were cigarette smokers.

In this research, the use of the same clothes at home and during spraying was not a risk factor because the shallot fields were very far from the farmer's house, and they changed their clothes for work. They left early in the morning and went home during the day and sometimes even in the afternoon. Next, $<10 \%$ of farmers used the same clothes after arriving home, both in the infertile (case) and fertile (control) groups. The use of soap for washing their hands after spraying was not significantly associated with the infertility cases. After spraying, farmers washed their hands with the water inundated in the field.

The length of being a farmer was not a risk factor for infertility, while no availability of information exists on their frequent use of pesticides in the past or explaining the use of herbicides. A study shows the decrease in semen parameters in plantation and agricultural workers related to the use of herbicides ${ }^{25}$. Longterm exposure to low-dose chemicals relates to human health effects, including decreased immunity, endocrine disorders, reproductive disorders, and cancer ${ }^{26}$.

The result indicated that those farmers who sprayed pesticides more than three times a week were three times greater than likely to experience infertility than those who applied less than three times a week (OR: $2.4 \mathrm{Cl}: 1.1$ - 5.4, $p$ value 0.029), and those who worked more than 6 hours a day were 3 times greater than likely to experience infertility than those who applied less than 6 hours a day (OR: $2.3 \mathrm{Cl}: 1.0$ - 5.1, p-value 0.044). Similarly, farmers who said to practice re-spraying pesticides were less likely to experience infertility than those who did not repeat spraying pesticides (OR: $0.4, \mathrm{Cl}: 0.2-0.8$, $p$-value 0.016, a: 0.05). Subsequently, the practice among farmers who do not follow the product prescription standard in pesticide use, the load of pesticide exposure of pesticides among farmers is unpredictable and unmeasurable. Since the farmers commonly spray pesticides according to their wishes, recall bias among farmers could occur.

The amount of mixture of pesticides can affect the effect of cell and phenotypic changes. Exposed to low-dose pesticide mixtures in vitro affects mesenchymal stem cells (MSC). The permanent phenotypic modification is related to oxidative stress, the emergence of adipogenesis differentiation, and the tendency to exhibit tumorigenic struma. A typical mixture of pesticides causes premature aging of mesenchymal stem cells (MSC). It accelerates the emergence of age-related to the benchmark dose (BMD) analysis showed that the ecotoxicity of pesticides active ingredients is increasing when a mixture of 2 or more pesticide use simultaneously. Ecotoxicity also appears high in a mixture of lower doses compared to higher ones $^{28}$. Surprisingly, (OR: 0.4, Cl: 0.2-0.9) pvalue 0.029 , a: 0.05 among farmers who ate foods fertility functional. Also, surprisingly, (OR: 0.4, Cl: 0.2-0.9) p-value 0.029, a: 0.05 among farmers who ate foods fertility functional. Daily zinc intake is associated with infertile events, but zinc intake cannot describe the chronic incidence of food exposure with infertility. Farmers who consume fertility-enhancing foods such as salmon, squid, chocolate, duck meat, chicken, and fish are more likely to be infertile, and this is because the amount of food consumption to increase fertility is inadequate. Zinc in the plasma and urine is the best indicator currently available. ${ }^{29}$ Zinc levels in seminal plasma exhibit limited predictive value because zinc is an intracellular ion whose levels fluctuate according to circadian rhythms. Sufficient zinc can synthesize testosterone and improve spermatogenesis $^{12}$. Zinc supplementation can increase serum $\mathrm{FSH}, \mathrm{LH}$, and testosterone ${ }^{30}$. Zinc deficiency affects testicular function directly either in testicular steroidogenesis and or indirectly through its effect on pituitary synthesis and or prolactin secretion ${ }^{31}$.

A previous study found that the variability of the pesticide effect is due to the different vulnerability of each individual due to genetic polymorphism.

Regarding limitations, this study did not specify the amount of pesticide mixture for spraying. The researcher did not specify the frequency of re-spraying the harvested shallots seeds and the types of pesticides used. Future studies need to examine pesticide residues in the farmers by measuring the levels of DAP (dialkyl phosphate) pesticide residues in urine ${ }^{15}$.

Infertile and fertile farmers practiced unsafe procedures, mixing pesticides excessively ( >5 types), re-spraying onion seeds, personal hygiene after spraying, and storing them in the house. Variables that exhibited a significant effect were the frequency of pesticide spraying in a week, spraying against the wind direction, and repeated spraying. The most significant variable was frequency of pesticide spraying in a week. $(\operatorname{Exp}(\mathrm{B}): 2.4(\mathrm{Cl}=1.1-5.4)$.

\section{CONCLUSION}

The conclusion of this study is that the variable with the highest effect was frequency of pesticide spraying in a week. Farmers with the frequency of pesticide spraying the red shallot $>$ 
3 in a week exhibited an infertile tendency 3 times higher than farmers who did spray pesticide $\leq 3$ in a week.

\section{ACKNOWLEDGMENTS}

The authors would like to thank the respondents in Pamulihan Village, Brebes. The authors would like to acknowledge a gratitude thank to Diponegoro University to provide financial support for this study (Grant No. 38522/UN7.P4.3/PP/2019)

\section{Conflict of interest}

The author has no real or potential conflict of interest regarding the study presented.

\section{REFERENCES}

1. Zegers-Hochschild F, Adamson GD, de Mouzon J, Ishihara O, Mansour R, Nygren $\mathrm{K}$, et al. International Committee for Monitoring Assisted Reproductive Technology (ICMART) and the World Health Organization (WHO) revised glossary of ART terminology. Fertil Steril [Internet]. 2009 Nov [cited 2017 Dec 5];92(5):1520-4. Available from: http: / / www.ncbi.nlm.nih.gov/pubmed/1 9828144

2. Gurunath S, Pandian Z, Anderson RA, Bhattacharya S. Defining infertility-a systematic review of prevalence studies. Hum Reprod Update. 2011;17(5):575-88.

3. Vayena E, Rowe PJ, Griffin D. Medical, ethical \& social aspects of assisted reproduction. Geneva, Switzerland: WHO; 2002.

4. Boivin J, Bunting L, Collins JA, Nygren KG. International estimates of infertility prevalence and treatment-seeking: potential need and demand for infertility medical care. Hum Reprod [Internet]. 2007 Jun 1 [cited 2017 Dec 5];22(6):150612. Available from: http: / / www.ncbi.nlm.nih.gov/pubmed/1 7376819

5. Bennett LR, Wiweko B, Hinting A, Adnyana IP, Pangestu $M$. Indonesian infertility patients' health seeking behaviour and patterns of access to biomedical infertility care: an interviewer administered survey conducted in three clinics. Reprod Health [Internet]. 2012;9(1):24. Available from: http: / / reproductive-health-

journal.biomedcentral.com/articles/10.1 186/1742-4755-9-24

6. Bennett LR, Wiweko B, Bell L, Shafira N, Pangestu M, Adayana I. P, et al.
Reproductive knowledge and patient education needs among Indonesian women infertility patients attending three fertility clinics. Patient Educ Couns [Internet]. 2015 Mar 1 [cited 2017 Dec 5];98(3):364-9. Available from: http://www.sciencedirect.com/science/a rticle/pii/S0738399114004893

7. Nene UA, Coyaji K, Apte H. Infertility: A label of choice in the case of sexually dysfunctional couples. Patient Educ Couns [Internet]. 2005 Dec [cited 2017 Dec 6];59(3):234-8. Available from: http://www.ncbi.nlm.nih.gov/pubmed/1 6242294

8. Fritz MA, Speroff L. Clinical gynecology endocrinology and infertility. In: 8th edition. Philadelphia: Lippincot Williams \& Wilkins.; 2005. p. 1451.

9. Maret W, Sandstead HH. Zinc requirements and the risks and benefits of zinc supplementation. J Trace Elem Med Biol. 2006;20(1):3-18.

10. Menteri, Kesehatan. Peraturan Menteri Kesehatan Republik Indonesia no 75 tahun 2013 tentang Angka Kecukupan Gizi yang Dianjurkan Bagi Bangsa Indonesia [Internet]. 2013. Available from: https: / / peraturan.bkpm.go.id/jdih/userfi les/batang/PMK No. 75 ttg Angka Kecukupan Gizi Bangsa Indonesia.pdf

11. Azadeh Sedigh $M M$ and AP. Effect of Organic and Mineral Zinc Supplement in Diet on Reproductive Hormones in Mice. Int J Anim Vet Adv. 2014;6(2):77-9.

12. Liu YL, Zhang MN, Tong GY, Sun SY, Zhu $\mathrm{YH}, \mathrm{Cao} \mathrm{Y}$, et al. The effectiveness of zinc supplementation in men with isolated hypogonadotropic hypogonadism. Asian J Androl. 2017;19(July 2016):280-5.

13. Mehrpour O, Karrari P, Zamani N, Tsatsakis AM, Abdollahi M. Occupational exposure to pesticides and consequences on male semen and fertility: A review. Toxicol Lett [Internet]. 2014;230(2):14656. Available from: http://dx.doi.org/10.1016/j.toxlet.2014. 01.029

14. Peiris-John RJ, Wickremasinghe R. Impact of low-level exposure to organophosphates on human reproduction and survival. Trans R Soc Trop Med Hyg. 2008;102(3):239-45.

15. Sifakis $S$, Mparmpas $M$, Soldin OP, Tsatsakis A. Pesticide Exposure and Health Related Issues in Male and Female 
Reproductive System. Pestic - Formul Eff Fate [Internet]. 2011;495-526. Available from:

http: / /www.intechopen.com/books/pesti cides-formulations-effects-fate/pesticideexposure-and-health-related-issues-inmale-and-female-reproductive-system

16. Sengupta P, Banerjee R. Environmental toxins: Alarming impacts of pesticides on male fertility. Hum Exp Toxicol. 2014;33(10):1017-39.

17. Melgarejo $M$, Mendiola J, Koch HM, Moñino-García M, Noguera-Velasco JA, Torres-Cantero AM. Associations between urinary organophosphate pesticide metabolite levels and reproductive parameters in men from an infertility clinic. Environ Res. 2015;137:292-8.

18. Perry MJ, Venners SA, Barr DB, Xu X. Environmental pyrethroid and organophosphorus insecticide exposures and sperm concentration. Reprod Toxicol. 2007;23(1):113-8.

19. As'ady A, Supangat, Indreswari L. Analysis of Personal Protective Equipments Pesticides Usage Effects on Health Complaints of Farmers in Pringgondani Village Sumberjambe District Jember Regency. J Agromedicine Med Sci. 2019;5(1):31-8.

20. Min AZ, Robson MG, Siriwong W. Effects of pesticide exposure on reproductivity of male groundnut farmers in Kyauk Kan village , Nyaung-U , Mandalay region , Myanmar. Risk Manag Healthc Policy. 2018;11:235-41.

21. Hernndez-Valero MA, Bondy ML, Spitz MR, Zahm SH. Evaluation of Mexican American migrant farmworker work practices and organochlorine pesticide metabolites. Am $\mathrm{J}$ Ind Med. 2001;40(5):554-60.

22. Damalas CA, Eleftherohorinos IG. Pesticide exposure, safety issues, and risk assessment indicators. Int $\mathrm{J}$ Environ Res Public Health. 2011;8(5):1402-19.

23. Lichtenberg E, Zimmerman R. Adverse health experiences, environmental attitudes, and pesticide usage behavior of farm operators. Risk Anal. 1999;19(2):283-94.

24. Bhandari G, Atreya K, Yang X, Fan L, Geissen V. Factors affecting pesticide safety behaviour: The perceptions of Nepalese farmers and retailers. Sci Total Environ. 2018;631-632:1560-71.
Herbicide Exposure on Seminal Parameters among Oil Palm Plantation Workers in Lampung Province, Indonesia. Am J Biomed Res. 2014;2(4):83-7.

26. J. Srinivasa PM, D'Souza JU. Effects of Pesticides on Male Reproductive Functions. Iran J Med Sci. 2005;30(4).

27. Hochane $M$, Trichet V, Pecqueur C, Avril $P$, Oliver $L$, Denis $J$, et al. Low-Dose Pesticide Mixture Induces Senescence in Normal Mesenchymal Stem Cells (MSC) and Promotes Tumorigenic Phenotype in Premalignant MSC. Stem Cells [Internet]. 2017 Mar [cited 2019 Feb 17];35(3):80011. Available from: http://www.ncbi.nlm.nih.gov/pubmed/2 7860054

28. Yang G, Li J, Wang $Y$, Chen $C$, Zhao $H$, Shao K. Quantitative ecotoxicity analysis for pesticide mixtures using benchmark dose methodology. Ecotoxicol Environ Saf [Internet]. 2018;159(April):94-101. Available from: https: //doi.org/10.1016/j.ecoenv.2018.0 4.055

29. Wieringa FT, Dijkhuizen MA, Fiorentino $M$, Laillou A, Berger J. Determination of zinc status in humans: Which indicator should we use? Nutrients. 2015;7(5):3252-63.

30. Shahraki MR, Forghani T, Mohammadi M, Khazaei-feizalabad A. The Effect of Intraventricular Administration of Zinc on Serum LH, FSH, Prolactin and Testosterone in Male Rats. Zahedan J Res Med Sci. 2015;17(9):29-32.

31. Karaca Z, Tanriverdi F, Kurtoglu S, Tokalioglu S, Unluhizarci K, Kelestimur F. Pubertal arrest due to $\mathrm{Zn}$ deficiency: the effect of zinc supplementation. Hormones (Athens). 2007;6(1):71-4

25. Sutyarso S, Kanedi M. Impacts of 